\title{
Resonance Light Scattering Spectroscopy of $\beta$-Cyclodextrin- Sodium Dodecylsulfate-Protein Ternary System and Its Analytical Applications
}

\author{
Zhanguang Chen, ${ }^{* \dagger}$ Jinbin LIU,* Xiaoming Chen, ** Taiyu Zhang,* and Yali HAN* \\ *Department of Chemistry, Shantou University, Shantou 515063, P. R. China \\ **Institute of Chemistry, Xiangtan University, Xiangtan 411105, P. R. China
}

\begin{abstract}
A simple, highly sensitive and dye-less assay for proteins was reported using a resonance light-scattering (RLS) technique based on the enhanced RLS intensity of $\beta$-cyclodextrin ( $\beta$-CD)-sodium dodecylsulfate (SDS)-protein system. Under the optimum conditions, the enhanced RLS intensity is in proportion to the concentration of proteins in the range of 0.01 to $2.3 \mu \mathrm{g} \mathrm{ml}^{-1}$ for bovine serum albumin (BSA), 0.01 to $2.0 \mu \mathrm{g} \mathrm{ml}^{-1}$ for human serum albumin (HSA), $0.015 \mathrm{to} 5.0 \mu \mathrm{g} \mathrm{ml}^{-1}$ for $\gamma$-globulin $(\gamma-\mathrm{G}), 0.02$ to $3.5 \mu \mathrm{g} \mathrm{ml}^{-1}$ for egg albumin (EA), 0.02 to $4.0 \mu \mathrm{g} \mathrm{ml}{ }^{-1}$ for pepsin (Pep), and 0.02 to $3.6 \mu \mathrm{g} \mathrm{ml}^{-1}$ for $\alpha$-chymotrypsin (Chy). Their detection limits $(S / N=3)$ are 1.1, 1.6, 2.4, 6.7, 5.4 and $4.2 \mathrm{ng} \mathrm{ml}^{-1}$, respectively. Synthetic samples and human serum samples were determined satisfactorily, and the results were in reasonable agreement with those obtained by a documented spectrophotometric (Bradford) method.
\end{abstract}

(Received January 19, 2007; Accepted May 9, 2007; Published November 10, 2007)

\section{Introduction}

Accurate determination of protein concentration is of great importance in many fields, such as chemical and biochemical analysis, clinical analysis and biotechnology. Traditional spectrophotometric methods for protein determination using dyes as analytical reagents, such as the Biuret, ${ }^{1}$ Lowry, ${ }^{2}$ and Bradford $^{3}$ methods, have their disadvantages. They have limited sensitivity and are time-consuming or complicated to operate. ${ }^{4}$ In order to solve some of these problems, researchers have developed chemiluminescence, ${ }^{5,6}$ fluorescence ${ }^{7,8}$ and resonance light scattering (RLS) $)^{9,10}$ methods. Among these developed procedures, RLS methods have gained increasing attention due to their convenience, high sensitivities, and superior tolerance to interferences.

The RLS technique used with common spectrofluorometers can compensate for the drawbacks of spectrophotometric and spectrofluorometric measurements and has found wide applications in the detection of nucleic acids, ${ }^{11-14}$ proteins, ${ }^{15,16}$ amino acid, ${ }^{17}$ saccharide ${ }^{18,19}$ and medicines. ${ }^{20,21}$ In this research, we studied the characteristics of RLS spectra of $\beta$-cyclodextrin $(\beta$-CD)-sodium dodecylsulfate (SDS)-protein ternary system, and the mechanisms of their interaction. At $\mathrm{pH} 3.0$, protein, $\beta$-CD and SDS bind to form a three-component complex ( $\beta$-CD-SDS-protein), which strongly enhances the RLS intensity. The enhanced RLS intensity was in proportion to the concentration of proteins even down to nanogram levels. $\beta-\mathrm{CD}$ is a cyclic oligomer composed of seven $\alpha$-D-glucopyranose rings connected by $1,4^{\prime}-O$-glycosidic bonds. ${ }^{22}$ It has a hollow truncated cone with a hydrophobic cavity and hydrophilic walls and can form inclusion complexes with guest organic or

$\dagger$ To whom correspondence should be addressed.

E-mail:kqlu@stu.edu.cn inorganic molecules with suitable polarities and dimensions. The formation of a supramolecular complex with $\beta$-CD can alter the photochemical and photophysical properties of the guest molecules. Thus considerable attention has been focused on the development of applications of the $\beta$-CD. Its inclusion ability for organic substrates has been widely used in pharmaceutical industries and for analytical purposes. ${ }^{23,24}$ Nevertheless, an assay procedure that utilizes $\beta$-CD and SDS as probe for the determination of protein concentrations with RLS technique has not been reported yet. In this paper, we report that the interaction of the proteins with $\beta$-CD and SDS results in substantial RLS signal enhancement of the $\beta$-CD-SDS system. A simple and highly sensitive assay method for proteins has been developed based on this phenomenon.

\section{Experimental}

\section{Reagents and chemicals}

The stock solutions of proteins were prepared by dissolving commercially purchased proteins in doubly distilled water. The concentration of the working solution was $20.0 \mu \mathrm{g} \mathrm{ml}^{-1}$ by diluting the protein stock solutions. Proteins in this work included bovine serum albumin (BSA), human serum albumin (HSA) (Sino-American Biotechnology Company, Beijing), $\gamma$-globulin $(\gamma-\mathrm{G})$, egg albumin (EA) (Sigma, St. Louis, MO, USA), pepsin (Pep, Fangcao Medical Industrial Co., Shanghai) and $\alpha$-chymotrypsin (Chy, Shanghai Institute of Biochemistry, Shanghai). They were all stored at $0-4^{\circ} \mathrm{C}$.

$\beta$-Cyclodextrin $(\beta$-CD) was obtained from Kermel Chemical Reagent Development Center (Tianjin, China). Its stock solution was prepared by dissolving the product in doubly distilled water; the concentration of its working solution was $5.0 \times 10^{-4} \mathrm{~mol} \mathrm{l}^{-1}$. The working concentration of sodium dodecylsulfate (SDS) (Merck, Germany) was $1.0 \times 10^{-3} \mathrm{~mol} \mathrm{l}^{-1}$. 


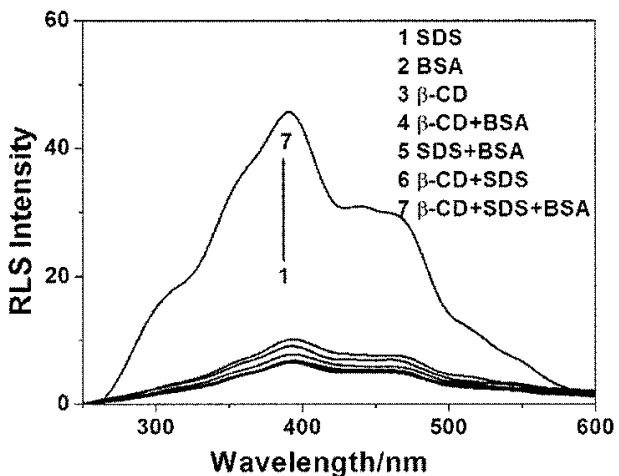

Fig. 1 RLS spectra of the interaction of $\beta$-CD-SDS and BSA. Conditions: $\beta$-CD, $5.0 \times 10^{-5} \mathrm{~mol} \mathrm{l}^{-1}$; SDS, $8.0 \times 10^{-5} \mathrm{~mol} \mathrm{l}^{-1}$; $\mathrm{pH}$, 3.00. BSA $\left(\mu \mathrm{g} \mathrm{ml}^{-1}\right)$ : line $2,10.0$; lines $4,5,7,1.0$.

Coomassie Brilliant Blue G-250 (CBB) was obtained from Fluka. The working solution was prepared by dissolving 0.0836 $\mathrm{g}$ of the crystal in $50 \mathrm{ml}$ of $95 \%$ ethanol and then mixing with $100 \mathrm{ml} 85 \%$ phosphoric acid. The mixture was diluted to 1000 $\mathrm{ml}$ with doubly-distilled water. The concentration of the working solution was $1.0 \times 10^{-5} \mathrm{~mol} \mathrm{l}^{-1}$.

Britton-Robinson (BR) buffer solution $\left(0.04 \mathrm{~mol} \mathrm{l}^{-1}\right.$ phosphoric acid, $0.04 \mathrm{~mol} \mathrm{l}^{-1}$ acetic acid, $0.04 \mathrm{~mol} \mathrm{l}^{-1}$ boric acid, $0.2 \mathrm{~mol} \mathrm{l}^{-1}$ sodium hydroxide) was used to control the acidity of the solution, and $0.5 \mathrm{~mol} \mathrm{l}^{-1} \mathrm{NaCl}$ solution was used to adjust the ionic strength of the aqueous solution.

Human serum samples were bought from Shantou Central Hospital and diluted with doubly distilled water. All chemicals used were of analytical grade or the best grade commercially available and doubly distilled water was used throughout.

\section{Apparatus}

The RLS spectra and fluorescence spectra were measured with a Perkin-Elmer Model LS-55 spectrofluorometer equipped with a quartz cuvette $(1 \times 1 \mathrm{~cm})$. An SA 720 instrument (Orion Research) was used to measure the $\mathrm{pH}$ of the solution. Atomic force microscopy images were measured with a Multimode NanoscopIIIa AFM (Digital Instruments).

\section{General procedures}

Into a 10-ml calibrated flask were added $1.0 \mathrm{ml}$ of Britton-Robinson buffer, $1.0 \mathrm{ml}$ of the working solution of $\beta$-CD, $0.8 \mathrm{ml}$ of SDS and appropriate amounts of proteins (or samples); then the mixture was diluted to $10.0 \mathrm{ml}$ with doubly distilled water and stirred thoroughly.

All RLS spectra were obtained by scanning simultaneously the excitation and emission monochromators $(\Delta \lambda=0.0 \mathrm{~nm})$ from 250.0 to $600.0 \mathrm{~nm}$ with the excitation and emission slits $5.0 \mathrm{~nm}$ wide. The RLS intensities were measured at $393.0 \mathrm{~nm}$. The enhanced RLS intensity of the system by proteins was represented as $\Delta I_{\text {RLS }}=I_{\text {RLS }}-I^{0}{ }_{\text {RLS }}\left(I_{\text {RLS }}\right.$ and $I_{\text {RLS }}^{0}$ were the RLS intensities of the systems with and without proteins).

\section{Results and Discussion}

\section{Spectral characteristics and reaction}

The RLS spectra of the $\beta$-CD-SDS-BSA ternary system under optimum conditions $\left(5.0 \times 10^{-5} \mathrm{~mol} \mathrm{l}^{-1} \beta\right.$-CD; $8.0 \times 10^{-5} \mathrm{~mol} \mathrm{l}^{-1}$ SDS; pH 3.0) are shown in Fig. 1. The RLS intensities of BSA $\left(10.0 \mu \mathrm{g} \mathrm{ml}^{-1}\right.$ ) (line 2), $\beta$-CD (line 1) and SDS (line 3) were (a)

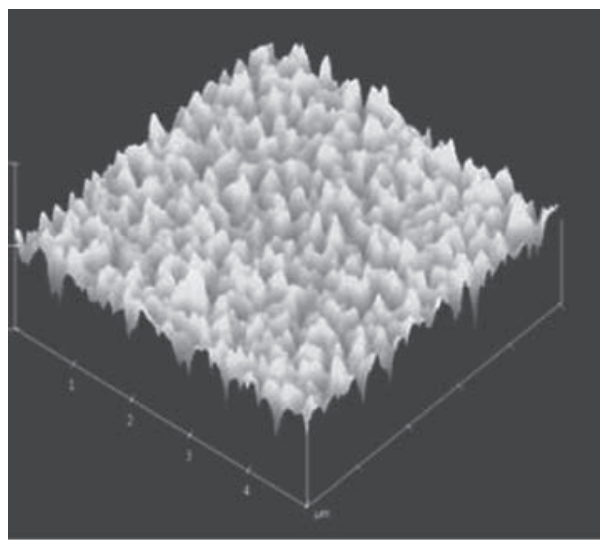

(b)

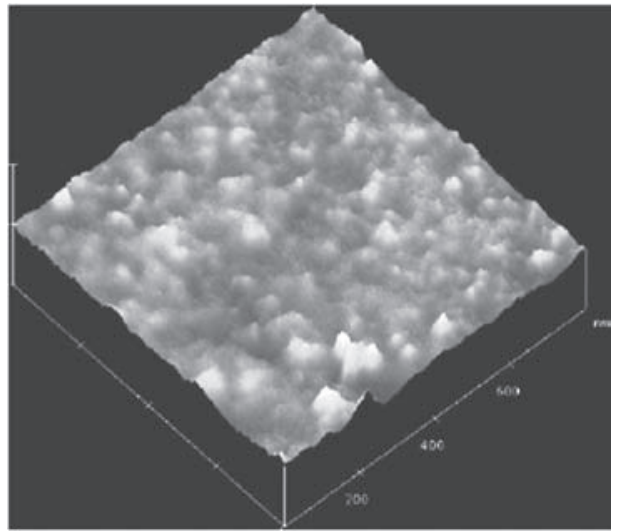

(c)

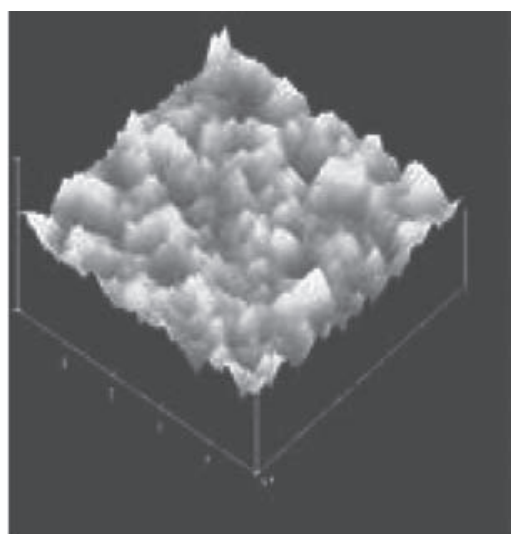

Fig. 2 AFM images of $\beta$-CD-SDS (a), SDS-BSA (b), and $\beta$-CDSDS-BSA (c) particles. Conditions: $\beta$-CD, $5.0 \times 10^{-5} \mathrm{~mol} \mathrm{l}^{-1}$; SDS $8.0 \times 10^{-5} \mathrm{~mol} \mathrm{l}^{-1} ; \mathrm{pH}, 3.00 ; \mathrm{BSA}, 1.0 \mu \mathrm{g} \mathrm{ml}^{-1}$.

very weak in the wavelength range of $250-700 \mathrm{~nm}$. The enhanced RLS intensity could be observed when a trace amount of BSA was added to the $\beta$-CD or the SDS solution (lines 4 and $5)$. But the enhanced RLS intensities were not clear. However, when BSA was added into $\beta$-CD in the presence of SDS, great synergistic enhancement can be observed, especially for the peak at $393.0 \mathrm{~nm}$ which increased remarkably. These enhanced RLS signals increase with increasing concentration of proteins. In this paper, the $393.0 \mathrm{~nm}$ peak was chosen for further study.

Aggregate size is one of the most important factors that influence the RLS intensity of the system. ${ }^{25}$ The interaction between the $\beta$-CD-SDS and BSA forms large particles. The larger the size of the particle, the stronger the signal of the scattering light that would be produced. ${ }^{26}$ This could lead to the strong enhancement of the RLS intensity of the $\beta$-CD-SDS 


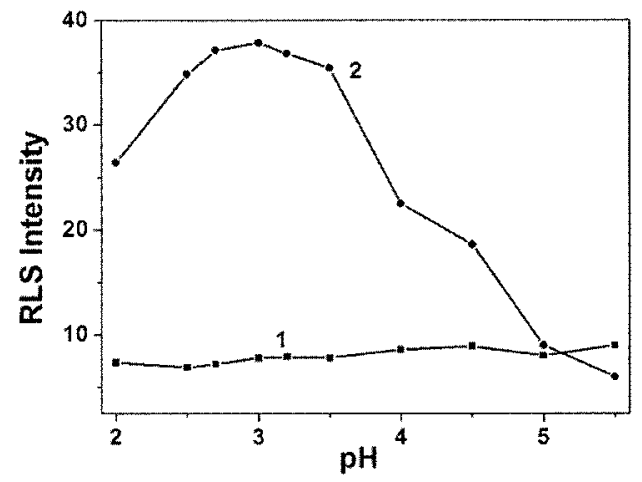

Fig. 3 Dependence of the RLS intensity on the pH. (1) $I_{\text {RLS }}^{0}$, (2) $\Delta I_{\text {RLS. }}$. Conditions: $\beta$-CD, $5.0 \times 10^{-5} \mathrm{~mol} \mathrm{l}^{-1}$; SDS, $8.0 \times 10^{-5} \mathrm{~mol} \mathrm{l}^{-1}$; BSA, $1.0 \mu \mathrm{g} \mathrm{ml}^{-1}$.

system. This was also confirmed by the results obtained from the AFM images (as shown in Fig. 2). The mixed solutions of $\beta$-CD-SDS, SDS-BSA and $\beta$-CD-SDS-BSA system were distributed over a $0.8 \times 0.8 \mathrm{~cm}$ plane glass, and dried naturally at room temperature. The dried samples were then fixed on the observation platform for AFM detection. If we compare their particle sizes, we find that large particles were formed when the $\beta$-CD-SDS-BSA ternary system formed.

\section{Effect of $\mathrm{pH}$ and buffers}

The effect of $\mathrm{pH}$ on the enhanced RLS intensity of the system is shown in Fig. 3. The experimental results indicate that the RLS intensity reached a maximum around $\mathrm{pH}$ 3.0. This may be related to the isoelectric point of proteins. Proteins are positively charged when the $\mathrm{pH}$ is lower than their isoelectric points. In acidic medium, the electrostatic interaction between $\beta$-CD-SDS and proteins could be very strong, which could be favorable for the RLS intensity enhancement. The effects of different buffers (Britton-Robinson, HAc-NaAc, $\mathrm{Na}_{2} \mathrm{HPO}_{4}{ }^{-}$ citric acid, Walpole and potassium hydrogen phthalate- $\mathrm{HCl}$ ) on the enhanced RLS intensity of $\beta$-CD-SDS-BSA system were also tested at the same $\mathrm{pH}(\mathrm{pH}$ 3.0). Britton-Robinson gave the maximum enhancement of RLS intensity. So the $\mathrm{pH} 3.0$ Britton-Robinson was the most suitable buffer.

\section{Effect of the $\beta$-CD concentration}

As shown in Fig. 4, the concentration of $\beta$-CD significantly influenced the RLS intensity of the $\beta$-CD-SDS-BSA system. Figure 4 shows clearly that $\beta$-CD concentration in the range of $1.0 \times 10^{-5}$ to $1.0 \times 10^{-4} \mathrm{~mol} \mathrm{l}^{-1}$ had a great influence on the RLS intensity. With increasing $\beta$-CD concentration, the $\Delta I_{\mathrm{RLS}}$ values increased; they reached a maximum at $5.0 \times 10^{-5} \mathrm{~mol} \mathrm{l}^{-1}$. Then an increase of $\beta$-CD concentration led to a reduction of the RLS intensity. So $5.0 \times 10^{-5} \mathrm{~mol} \mathrm{l}^{-1} \beta$-CD was selected in this assay.

\section{Effect of the surfactants}

In order to test the effect of kinds of surfactant, we examined five kinds of surfactants, including sodium dodecylsulfonate, hexadecyltimethylammonium bromide, cetylpyridinium bromide, Triton X-100 and OP, in this study. The enhanced RLS intensity with SDS was maximal, thus SDS was chosen for the further study. As shown in Fig. 5, the concentration of SDS not only influenced the enhanced RLS intensity $\left(\Delta I_{\text {RLS }}\right)$ but also influenced $I^{0}$ RLS. When the concentration of SDS was low, the $\Delta I_{\text {RLS }}$ value increased rapidly along with the increasing concentration of SDS. Then the $\Delta I_{\text {RLS }}$ value of the system

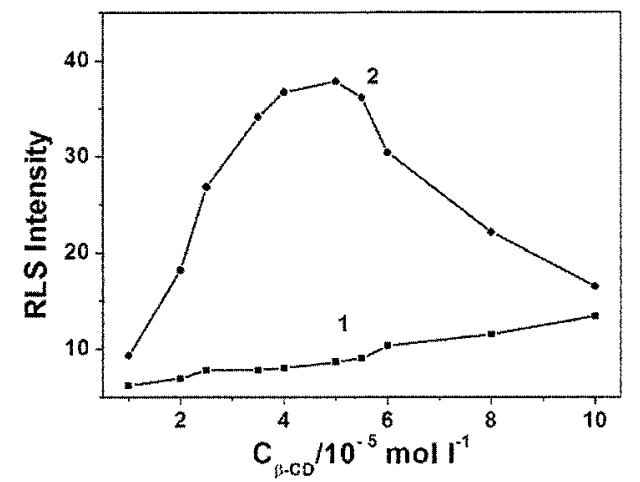

Fig. 4 Dependence of the RLS intensity on the $\beta$-CD concentration. (1) $I_{\text {RLS }}^{0}$, (2) $\Delta I_{\text {RLS. }}$. Conditions: pH, 3.00; SDS, $8.0 \times$ $10^{-5} \mathrm{~mol} \mathrm{l}^{-1}$; BSA, $1.0 \mu \mathrm{g} \mathrm{m} \mathrm{l}^{-1}$.

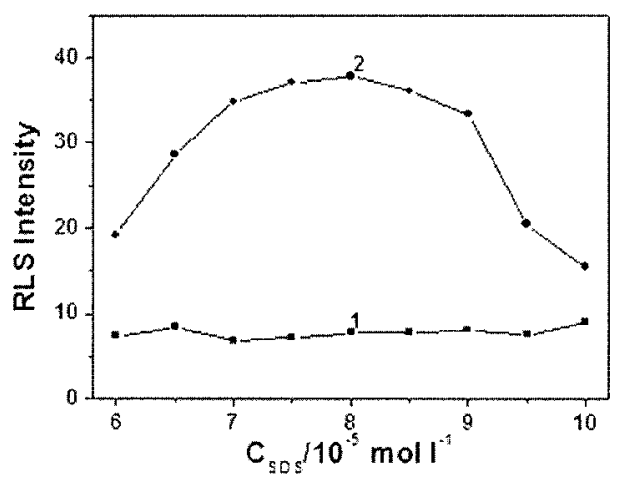

Fig. 5 Dependence of the RLS intensity on the SDS concentration. (1) $I_{\text {RLS }}^{0}$, (2) $\Delta I_{\text {RLS. }}$ Conditions: $\mathrm{pH}, 3.00 ; \beta-\mathrm{CD}, 5.0 \times 10^{-5} \mathrm{~mol} \mathrm{l}^{-1}$; BSA, $1.0 \mu \mathrm{g} \mathrm{ml}^{-1}$.

reached a maximum and decreased when the concentration of SDS was higher than $8.0 \times 10^{-5} \mathrm{~mol}^{-1}$. When the concentration of SDS reached its critical micelle concentration (CMC), $\beta-\mathrm{CD}$ was distributed into the micellar system; thus the RLS intensity was reduced. Therefore, $8.0 \times 10^{-5} \mathrm{~mol} \mathrm{l}^{-1} \beta$-CD was chosen in this assay.

\section{Effect of reagent addition order and stability}

The effect of addition order on the enhanced RLS intensity of the system was tested. Results showed that the order of buffer$\beta$-CD-SDS-protein was the best. In addition, the experiments show that the reaction occurred rapidly at room temperature after all reagents were mixed together, and the enhanced RLS of the system reached a maximum. Moreover, the RLS intensity remained stable for at least $90 \mathrm{~min}$. Thus, this bioassay is rapid and does not require crucial timing.

\section{Effect of ionic strength}

The effect of ionic strength on the enhanced RLS intensity of the system was studied over the $\mathrm{NaCl}$ concentration range from 0.025 to $0.2 \mathrm{~mol} \mathrm{l}^{-1}$. As shown in Fig. 6, with the increasing of the $\mathrm{NaCl}$ concentration, the enhanced RLS intensity had a small increase when the ionic strength was lower than $0.025 \mathrm{~mol} \mathrm{l}^{-1}$. Then the enhanced RLS intensity decreased when the ionic strength was higher than $0.025 \mathrm{~mol} \mathrm{l}^{-1}$. Because the ionic strength of the buffer used is very small, it can be neglected. One possible reason of this phenomenon is as follows. 


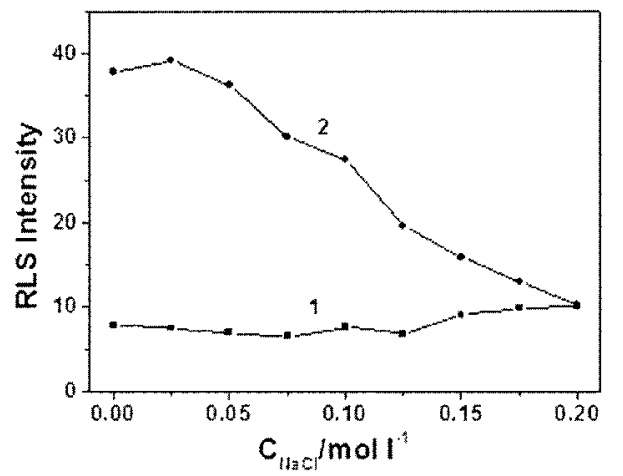

Fig. 6 Effect of ionic strength on the intensity of RLS. (1) $I^{0}{ }_{\mathrm{RLS}}$, (2) $\Delta I_{\text {RLS. }}$ Conditions: $\mathrm{pH}, 3.00 ; \beta$-CD, $5.0 \times 10^{-5} \mathrm{~mol} \mathrm{l}^{-1}$; SDS, $8.0 \times$ $10^{-5} \mathrm{~mol} \mathrm{l}^{-1}$; BSA, $1.0 \mu \mathrm{g} \mathrm{ml}^{-1}$.

Appropriately increasing the concentration of the salt will lead to a partial neutralization of the positive charges of the protein. As a result, the surface protection layer of protein could be destroyed and the surface energy would be increased, which favored the assembling of the dispersive particles. Thus the RLS intensity was increased. On the contrary, when the concentration of the $\mathrm{NaCl}$ was too high, the effect of the electrostatic shielding of charges, including the shielding of protein molecules from SDS and the shielding of SDS from protein molecules, reduced the combination of particles and resulted in a decreased RLS signal.

Interference of foreign substances

The effect of the foreign substances on the determination of only $1.0 \mu \mathrm{g} \mathrm{ml}^{-1}$ BSA was tested by pre-mixing BSA with compounds such as amino acids, nucleic acids, common ions, urea and sugars under the optimum conditions of the general procedure. The criterion for an interference was an $I_{\mathrm{RLS}}$ value varying by more than $5 \%$ from the value expected for BSA alone. There was no interference from the following foreign substances: 150-fold of histidine, leucine, glutamic acid, aspartate, lysine and tyrosine; 100-fold of glycine, cysteine, alanine and praline; 100-fold calf thymus DNA, fish sperm DNA and yeast RNA; 100-fold of $\mathrm{K}^{+}, \mathrm{Ca}^{2+}, \mathrm{Mg}^{2+}, \mathrm{Zn}^{2+}$ and $\mathrm{Cu}^{2+}$; 50-fold of $\mathrm{Mn}^{2+}, \mathrm{Cd}^{2+}$ and $\mathrm{Al}^{3+}$; 30-fold of $\mathrm{Ni}^{2+}, \mathrm{Pb}^{2+}, \mathrm{Co}^{2+}$ and $\mathrm{Fe}^{2+}$; 20-fold of $\mathrm{Fe}^{3+}$; 500-fold glucose; 200-fold urea Therefore, the present method has a good selectivity and can be applied to the direct determination of biological samples.

\section{Calibration curves and analytical applications}

Under the optimum conditions, linear relationships between the enhanced RLS intensity and the protein concentrations $(c)$ were constructed. All the analytical parameters have been regressed, and the results are shown in Table 1. Satisfactory linear relationships and low determination limits that range from 1.1 to $6.7 \mathrm{ng} \mathrm{ml}^{-1}$ depending on different kinds of proteins were obtained. Different proteins have different properties, furthermore, the size and the shape of the molecules are also different, ${ }^{27}$ so the RLS signals for various proteins were different. The limits of detection (LOD) were given by $3 S_{0} / S$; here 3 is a numerical factor chosen according to the confidence level desired, $S_{0}$ the standard deviation (S.D.) of the blank measurements $(n=13)$ and $S$ is the slope of calibration curve. A comparison of this method with other methods in terms of sensitivity is given in Table 2. One sees that the sensitivity of this method was higher than most of other methods. Therefore,
Table 1 Analytical parameters for the determination of various proteins

\begin{tabular}{lrlcl}
\hline & $\begin{array}{c}\text { Linear } \\
\text { range/ } \\
\mu \mathrm{g} \mathrm{ml}^{-1}\end{array}$ & $\begin{array}{c}\text { Regression } \\
\text { equation }\end{array}$ & $\begin{array}{c}\text { LOD, } \\
3 \sigma / \\
\mathrm{ng} \mathrm{ml}^{-1}\end{array}$ & $\begin{array}{l}\text { Correlation } \\
\text { coefficient, } r\end{array}$ \\
\hline BSA & $0.01-2.3$ & $\Delta I_{\text {RLS }}=6.6+28.7 c$ & 1.1 & $0.9990(n=13)$ \\
HSA & $0.01-2.0$ & $\Delta I_{\text {RLS }}=4.7+29.1 c$ & 1.6 & $0.9991(n=10)$ \\
$\gamma-\mathrm{G}$ & $0.015-5.0$ & $\Delta I_{\text {RLS }}=5.4+18.6 c$ & 2.4 & $0.9993(n=10)$ \\
EA & $0.02-3.5$ & $\Delta I_{\text {RLS }}=7.1+9.9 c$ & 6.7 & $0.9985(n=8)$ \\
Pep & $0.02-4.0$ & $\Delta I_{\text {RLS }}=2.5+13.8 c$ & 5.4 & $0.9986(n=8)$ \\
Chy & $0.02-3.6$ & $\Delta I_{\text {RLS }}=3.8+15.0 c$ & 4.2 & $0.9987(n=8)$ \\
\hline
\end{tabular}

a. Limit of detection.

Table 2 Comparison with some other assays of proteins

\begin{tabular}{llccc}
\hline Method & \multicolumn{1}{c}{ Reagent } & Protein & $\begin{array}{c}\text { Detection } \\
\text { limit/ng ml }\end{array}$ & Ref. \\
\hline Abs & Lowry & & $1.0 \times 10^{5}$ & 2 \\
Abs & CBB & & 5000 & 3 \\
Flu & Chrome Azurol S & HSA & 100 & 7 \\
Flu & ECR $^{\mathrm{a}}$ & HSA & 500 & 8 \\
RLS & TPPS $_{4}{ }^{\text {c }}$ & BSA/HSA & $18.0 / 53.5$ & 9 \\
RLS & Ponceau 4R & BSA/HSA & $6.96 / 5.71$ & 10 \\
RLS & Fast Green FCF & BSA/HSA & $1.86 / 1.18$ & 28 \\
RLS & Azophloxine & BSA/HSA & $2.38 / 2.34$ & 29 \\
RLS & $\beta$-CD-SDS & BSA/HSA & $1.1 / 1.6$ & This work \\
\hline
\end{tabular}

a. Eriochrome cyanine R.

b. $\alpha, \beta, \gamma, \delta$-Tetrakis 4-(sulfophenyl)porphine.

Table 3 Results for the determination of BSA in synthetic samples

\begin{tabular}{|c|c|c|c|c|}
\hline $\begin{array}{l}\text { BSA/ } \\
\mu \mathrm{g} \mathrm{ml}^{-1}\end{array}$ & $\begin{array}{l}\text { Main additives/ } \\
\qquad \mu \mathrm{g} \mathrm{ml}^{-1}\end{array}$ & $\begin{array}{l}\text { Found/ } \\
\mu \mathrm{g} \mathrm{ml}^{-1} \\
(n=5)\end{array}$ & $\begin{array}{c}\text { Recovery, } \\
\%\end{array}$ & $\begin{array}{c}\mathrm{RSD}, \% \\
(n=5)\end{array}$ \\
\hline 1.50 & $\begin{array}{l}\mathrm{Al}^{3+}(30), \text { His }(120), \\
\text { Phe }(100), \text { glucose } \\
(400), \text { urea }(150), \\
\mathrm{Pb}^{2+}(30)\end{array}$ & 1.52 & $97.4-102.3$ & 1.7 \\
\hline 1.50 & $\begin{array}{l}\text { Glu (150), Pro (100), } \\
\text { ctDNA }(100), \mathrm{Mn}^{2+} \\
(50), \mathrm{Fe}^{2+}(20), \\
\mathrm{Mg}^{2+}(10)\end{array}$ & 1.49 & $97.0-103.6$ & 2.6 \\
\hline
\end{tabular}

this method was rapid, simple and sensitive, and would be a valuable tool for the determination of proteins.

To test the present assay, the present method was applied to determine protein in synthetic samples and in real human serum samples. Synthetic samples for BSA containing metal ions, amino acids, nucleic acids, urea and glucose were analyzed, and the results are shown in Table 3 . The maximum relative standard deviation was $2.6 \%$ and the recovery was between 97.0 and $103.6 \%$. The results indicated that synthetic samples could be determined with good reproducibility by the proposed method.

Fresh human serum specimens obtained from Shantou University Hospital were also used for the analysis. The real human serum samples were stored at $0-4^{\circ} \mathrm{C}$, and tested without other preliminary treatment except for 1000 -fold dilution. Because the calibration curves of HSA and $\gamma-\mathrm{G}$ have different 
Table 4 Analytical results of human serum samples $(n=5)$

\begin{tabular}{cccccc}
\hline \multirow{2}{*}{$\begin{array}{c}\text { Serum } \\
\text { sample }\end{array}$} & \multicolumn{2}{c}{ This method } & & \multicolumn{2}{c}{ Bradford assay } \\
\cline { 2 - 3 } \cline { 5 - 6 } & Found/mg ml ${ }^{-1}$ & RSD, ${ }^{\text {a } \%}$ & & Found/mg ml ${ }^{-1}$ & RSD, ${ }^{\text {a } \%}$ \\
\hline 1 & $73.2 \pm 1.4$ & 2.2 & & $72.1 \pm 1.8$ & 2.6 \\
2 & $81.8 \pm 2.6$ & 1.9 & & $83.7 \pm 2.5$ & 3.4 \\
3 & $76.9 \pm 1.5$ & 3.4 & & $74.3 \pm 1.9$ & 2.5 \\
\hline
\end{tabular}

a. Relative standard deviation.

slopes, in order to determine the total protein in human serum samples, it is necessary to construct a calibration curve of standard human serum. Since the main contents of human serum are HSA and $\gamma-\mathrm{G}$, and their mass ratio is approximately $2: 1,{ }^{30}$ the standard human serum was obtained by mixing HSA with $\gamma-\mathrm{G}$ at the mass ratio of 2:1. The calibration curve for the standard human serum was $\Delta I_{\mathrm{RLS}}=4.9+22.5 \mathrm{C}\left(\mu \mathrm{g} \mathrm{ml}^{-1}\right)$. The results for the real human serum samples are shown in Table 4. The results were in accordance with the ones obtained by the Bradford assay. Results suggest that this method could be applied to the direct determination of protein in human serum samples without separation of interferences.

Interaction mechanism of $\beta-C D-S D S$ complex with protein

The cyclic glucose macromolecules of the $\beta$-CD have hydrophobic cavities and functional groups that can interact with proteins by weak forces similar to those involved in protein folding. ${ }^{31}$ The toroidal molecular structure of $\beta-\mathrm{CD}$ has a hydrophilic surface, making it water-soluble, whereas the cavity of the molecule is composed of the glucoside oxygen atoms and methane hydrogen atoms, giving it a hydrophobic character. As protein interacts with $\beta$-CD, some of the protein molecules including surface aromatic and hydrophobic residues normally locate in the $\beta$-CD cavity to achieve the maximum contact between the hydrophobic part of the guest and the apolar $\beta-\mathrm{CD}$ cavity. The hydrophilic part of the protein molecule remains, as far as possible, at the outer face of the compounds. ${ }^{32} \beta$-CD may interact with proteins via hydrophobic forces, hydrogen bonding and Van der Waals interactions; these forces were very useful for the enhanced RLS intensity.

In this system, the surfactant SDS has negative charge, whereas the proteins such as BSA and HSA are positively charged in the buffer medium $(\mathrm{pH} 3.0)$. Because of the electrostatic attraction forces, they can react easily to form an associate. As shown in Fig. 6, the RLS intensity increased, although slightly, at low ionic strength, which could mean that hydrophobic interactions was also engaged in this interaction. We concluded that in appropriate concentrations of SDS and below its isoelectric point the mode of protein-SDS interaction was electrostatic, accompanied by a small contribution of hydrophobic interactions, which led to formation of the associate. Thus the size of the aggregate increased, and this phenomenon was validated by the results obtained from the AFM images (Fig. 2). In fact, all these interactions occur simultaneously. Therefore, a rapid and sensitive method for the determination of proteins was developed.

\section{Conclusions}

The interaction of $\beta$-CD, SDS with protein enhanced the weak RLS of $\beta$-CD-SDS at pH 3.0, such enhancement was applied to the sensitive determination of proteins. This bioassay procedure has the advantages of high sensitivity, simplicity and high stability. In addition, this assay involves the using of $\beta$-CD as the probe, and thus the selectivity for proteins over interfering substances was improved. So, the method can be operated without any pretreatment of the sample except for dilution with water. It was applied to determine human serum samples satisfactorily, and the results were in agreement with ones obtained by the Bradford assay. From the experiment results, we conclude that this assay is rapid and easy to perform. This assay is very convenient to couple with other techniques such as flow injection analysis technique, and thus would be applicable to testing large numbers of biochemical samples. Therefore, this method is a valuable tool for the study and determination of proteins in both chemistry and biochemistry.

\section{Acknowledgements}

All authors express their sincere thanks for the support from the National Natural Science Foundation of China (No. 30271033) and the Municipal Science Foundation of Shantou (No. S02023).

\section{References}

1. L. X. Zhang and G. L. Wu, "Advanced Biochemical Experiments", 1989, Advanced Education Press, China, 192.

2. H. Lowry, N. J. Rosebrough, A. L. Farr, and R. J. Randall, J. Biol. Chem., 1951, 193, 265.

3. M. M. Bradford, Anal. Biochem., 1976, 72, 248.

4. X. Cong, Z. X. Guo, X. X. Wang, and H. X. Shen, Anal. Chim. Acta, 2001, 444, 205.

5. Z. P. Li, K. A. Li, and S. Y. Tong, Anal. Lett., 1999, 32, 901.

6. T. S. Gorimar, H. A. Hernandez, and M. W. Polczynski, Int. Clin. Prod. Rev., 1985, 4, 44.

7. Y. Saito, Y. Inden-Okazaki, S. Wada-Yano, A. Kanetsuna, K. Miyazaki, and M. Mifune, and Y. Tanaka, Anal. Chim. Acta, 1985, 178, 337.

8. Y. X. Ci and L. Chen, Analyst, 1988, 113, 679.

9. R. P. Jia, L. J. Dong, Q. F. Li, X. G. Chen, and Z. D. Hu, Talanta, 2002, 57, 693.

10. H. Zhong, J. J. Xu, and H. Y. Chen, Talanta, 2005, 67, 749.

11. C. Z. Huang, K. A. Li, and S. Y. Tong, Anal. Chem., 1996, $68,2259$.

12. Z. G. Chen, W. F. Ding, F. L. Ren, J. B. Liu, and Y. Z. Liang, Anal. Chim. Acta, 2005, 550, 204.

13. Z. G. Chen, W. F. Ding, F. L. Ren, Y. Z. Liang, Y. L. Han, and J. B. Liu, Microchim. Acta, 2005, 150, 34.

14. Z. G. Chen, W. F. Ding, F. L. Ren, and Y. L. Han, Anal. Lett., 2005, 38, 2301.

15. Z. G. Chen, J. B. Liu, and Y. Z. Liang, J. Biomol. Screen., 2006, 11,400 .

16. Z. G. Chen, T. Y. Zhang, F. L. Ren, and W. F. Ding, Microchim. Acta, 2006, 153, 65.

17. Z. G. Chen, J. B. Liu, Y. L. Han, and L. Zhu, Anal. Chim. Acta, 2006, 570, 109.

18. S. Z. Zhang, F. L. Zhao, K. A. Li, and S. Y. Tong, Anal. Chim. Acta, 2001, 431, 133.

19. S. Z. Zhang, F. L. Zhao, K. A. Li, and S. Y. Tong, Talanta, 2001, 54, 333.

20. S. P. Liu and L. Kong, Anal. Sci., 2003, 19, 1055.

21. S. P. Liu, L. Fan, X. L. Hu, Z. F. Liu, and S. Li, Anal. Sci., 
2006, 22, 819 .

22. P. Wallimann, T. Marti, A. Furer, and F. Diederich, Chem. Rev., 1997, 97, 1567.

23. J. B. Vincent, A. D. Sokolowski, T. V. Nguyen, and G. Vigh, Anal. Chem., 1997, 69, 4226.

24. R. J. Hurtubise, "Phosphorimetry Theory, Instrumentation and Applications", 1990, VCH, New York, 320.

25. R. F. Pasternack and P. J. Collings, Science, 1995, 269, 935.

26. Edition of Editorial Board of Chinese Macropaedia, "Chinese Macropaedia Biology(II)", 1991, Chinese Macropaedia Press, China, 1374.

27. Q. F. Li, X. G. Chen, X. Y. Zhang, C. X. Xue, S. H. Liu, and Z. D. Hu, Analyst, 2000, 125, 1483.

28. Y. F. Li, C. Z. Huang, and M. Li, Anal. Sci., 2002, 18, 177.

29. Q. Wei, D. Wu, Y. Li, B. Du, and J. H. Wang, Anal. Sci., 2006, 22, 275.

30. T. M. Wang, "Biochemistry and Detection Technology", 1993, Jiangsu Technology Press, Jiangsu, 162.

31. P. Pirzadeh, A. A. Moosavi-Movahedi, B. Hemmateenejad, F. Ahmadc, M. Shamsipur, and A. A. Saboury, Colloids Surf., B, 2006, 52, 31 .

32. Y. B. Han, K. J. Cheng, K. A. Simon, Y. M. Lan, P. Sejwal, and Y. Y. Luk, J. Am. Chem. Soc., 2006, 128, 13913. 